\title{
Purification of bovine pancreatic glucagon as a by-product of insulin production
}

\author{
A.S.R. Andrade 1 , \\ L. Vilela ${ }^{2}$ and \\ H. Tunes ${ }^{2}$
}

\author{
${ }^{1}$ Laboratório de Enzimologia, Departamento de Bioquímica, \\ Instituto de Ciências Biológicas, Universidade Federal de Minas Gerais, \\ Belo Horizonte, MG, Brasil \\ ${ }^{2}$ Departamento de Pesquisa e Desenvolvimento, BIOBRÁS S/A, Montes Claros, \\ MG, Brasil
}

\section{Correspondence \\ L. Vilela \\ BIOBRÁS S/A \\ Av. C, 1413, Distrito Industrial \\ 39404-004 Montes Claros, MG \\ Brasil \\ Fax: 55 (038) 229-6324 \\ Presented at the XXII Annual \\ Meeting of the Sociedade \\ Brasileira de Bioquímica, \\ Caxambu, MG, Brasil, May 1-4, 1993. \\ A.S.R. Andrade was the recipient of CAPES and BIOBRÁS S/A \\ fellowships.}

Received October 1, 1996 Accepted September 30, 1997

\begin{abstract}
A process for purifying bovine pancreatic glucagon as a by-product of insulin production is described. The glucagon-containing supernatant from the alkaline crystallization of insulin was precipitated using ammonium sulfate and isoelectric precipitation. The isoelectric precipitate containing glucagon was then purified by ion-exchange chromatography on Q-Sepharose FF, gel filtration on Sephadex G-25 and ion-exchange chromatography on S-Sepharose FF. A pilot scale test was performed with a recovery of $87.6 \%$ and a purification factor of 8.78 for the first chromatographic step, a recovery of $75.1 \%$ and a purification factor of 3.90 for the second, and a recovery of $76.2 \%$ and a purification factor of 2.36 for the last one. The overall yield was $50 \%$, a purification factor of 80.8 was obtained and the fraction containing active glucagon (suitable for pharmaceutical preparations) was $84 \%$ pure as analyzed by HPLC.
\end{abstract}

\section{Introduction}

Bovine pancreatic glucagon is a peptide secreted by the alpha cells of Langerhans islets which contains 29 amino acids and has a molecular mass of 3,485 Da calculated from its primary structure. Bovine glucagon has the same amino acid composition (1) as human (2) and porcine glucagon (3).

Pancreatic glucagon plays an important role in the maintenance of blood glucose concentration at normal levels and possibly also of free fatty acids and amino acids. Other related functions of glucagon include insulin release and regulation of protein catabolism. In addition, the hormone plays a role in the maintenance of normal cardiac function, regulation of urinary electrolyte excretion, renal and hepatic blood flow, appetite regulation, gastric secretion and gut motility.

Glucagon is used as a drug mainly in cases of hypoglycemia in insulin-dependent diabetics $(4,5)$, following insulin administration. Since prolonged hypoglycemic conditions may produce cortical injury, glucagon must be given in order to restore blood glucose to normal levels. Glucagon has also been used in the treatment of hypodynamic heart disorders (6) and hypotonic intestine (7).

Staub et al. (8) succeeded in isolating and crystallizing glucagon from an amorphous fraction obtained during the commercial purification of insulin. They employed repeated precipitation culminating in crystallization which was in itself a purification step. Re- 
cently glucagon separation has been based more directly on molecular size and charge. Pollock and Kimmel (9) used ion-exchange chromatography on CM-Sephadex and QAESephadex. Cole (10) used cation-exchange chromatography and buffers containing urea which is particularly beneficial since it not only permits chromatographic purification at $\mathrm{pH}$ values where glucagon has low solubility, but also helps to reduce protein selfassociation. Sundby and Markussen (11) developed a procedure applicable only to small-scale purification using the mother liquor fraction from the citrate crystallization of insulin brought to about half-saturation with $\mathrm{NaCl}$. Glucagon was obtained from the precipitate by gel filtration and isoelectric focusing.

The present paper describes a procedure for the purification of bovine glucagon using a starting material similar to that used by Sundby and Markussen (11). The glucagon in the mother liquor fraction from the alkaline crystallization of insulin was isolated by salting-out with ammonium sulfate and isoelectric precipitation.

The isoelectric precipitate was purified by ion-exchange chromatography on QSepharose FF in buffer containing urea, by gel filtration on Sephadex G-25, and by ionexchange chromatography on S-Sepharose FF. The process can be used for large-scale purification of glucagon $(470 \mathrm{mg}$ isoelectric precipitate containing $225 \mathrm{mg}$ glucagon as analyzed by radioimmunoassay (RIA), applied to a 45-1 Q-Sepharose column) and the hormone obtained has sufficient purity to be used in pharmaceutical formulations.

\section{Material and Methods}

\section{Radioimmunoassay}

The analysis was performed as described by Christofides (12). ${ }^{125}$ I-labeled glucagon obtained by the method of Bryant (13) was purified from free ${ }^{125} \mathrm{I}$ and other contami- nants by high performance liquid chromatography (HPLC) using a Nova Pak $\mathrm{C}_{18}$ column (Waters, Milford, MA) and an acetonitrile gradient in $0.1 \%$ trifluoroacetic acid. The fractions were collected into tubes containing PBS buffer. Glucagon antibodies and glucagon for the standard curves were obtained from Dr. Stephen R. Bloom (Royal Post Graduate Medical School, London). Glucagon for ${ }^{125}$ I labeling was obtained from Peninsula Laboratories (Belmont, CA).

\section{High performance liquid chromatography}

The analyses were performed at $45^{\circ} \mathrm{C}$ using a Pharmacia-LKB Biotechnology HPLC system consisting of two pumps (model 2152), a variable wavelength monitor (model 2151), an integrator recorder (model 2221) and a 4.6 x 250-mm Aquapore RP 300 column (Brownlee, Foster City, CA). A stepwise acetonitrile gradient consisting of $50,60,62,70$ and $80 \%$ buffer " $\mathrm{B}$ " ( 5 min for each concentration) was used (buffer "A", $50 \mathrm{mM}$ sodium phosphate, $10 \mathrm{mM}$ perchloric acid, $\mathrm{pH} 2.5$, and buffer "B", $50 \%$ acetonitrile in buffer "A"). The flow rate was 1 $\mathrm{ml} / \mathrm{min}$ and the elution was monitored by absorbance at $214 \mathrm{~nm}$. Commercial glucagon (Lilly) was used as a standard.

\section{Protein analysis}

Protein concentration was determined according to Lowry et al. (14) using BSA as standard.

\section{Ammonium sulfate and isoelectric precipitation}

Proteases present in the pancreatic extracts were precipitated with ammonium sulfate (commercial grade) according to Kunitz (15). The $\mathrm{pH}$ of the mother liquor of alkaline insulin crystals was adjusted to 2.5-3.0 with $3 \mathrm{~N} \mathrm{HCl}$. An amount of $452 \mathrm{ml}$ of $95 \%$ ethanol and $4.0 \mathrm{ml}$ of $20 \%$ zinc chloride was 
added (at a temperature of less than $20^{\circ} \mathrm{C}$ ) per liter of solution. The $\mathrm{pH}$ was adjusted to 2.1-2.2 with $3 \mathrm{~N} \mathrm{HCl}$ and $14 \mathrm{ml}$ of $50 \%$ ammonium sulfate solution per liter of mother liquor solution was added slowly. The $\mathrm{pH}$ was adjusted to $2.2-2.4\left(20-30^{\circ} \mathrm{C}\right)$, the suspension was stirred for $2 \mathrm{~h}$ and then left to stand unstirred for $12 \mathrm{~h}$ and filtered.

Glucagon in the supernatant was precipitated by adjusting the $\mathrm{pH}$ to its isoelectric point (pH 7.0) with $3 \mathrm{~N} \mathrm{HCl}$. After $24 \mathrm{~h}$ at $4^{\circ} \mathrm{C}$ glucagon was collected by filtration in a plate and frame filter press. Glucagon concentration was $10.5 \mathrm{mg} / \mathrm{g}$ isoelectric precipitate, as determined by RIA.

\section{Ion-exchange chromatography on Q-Sepharose FF}

The isoelectric precipitate was purified using a Q-Sepharose FF column $(2.0 \times 26$ $\mathrm{cm})$ from Pharmacia-LKB Biotechnology (Uppsala, Sweden). The column was eluted at room temperature with $50 \mathrm{mM}$ Tris- $\mathrm{HCl}, 7$ $\mathrm{M}$ urea, $\mathrm{pH} 9.0$, at a flow rate of $5.0 \mathrm{ml} / \mathrm{min}$. Before utilization, urea (commercial grade) solutions were purified by deionization in Amberlite MB-20 to $5 \mu \mathrm{S}$ conductivity. Forty$\mathrm{ml}$ samples (400 $\mathrm{mg}$ of isoelectric precipitate) were applied and eluted with a stepwise $\mathrm{NaCl}$ gradient. Fractions of $5 \mathrm{ml}$ were collected, absorbance at $280 \mathrm{~nm}$ was measured and glucagon was identified by RIA.

\section{Gel filtration chromatography on Sephadex G-25}

The glucagon fraction $(70 \mathrm{ml})$ from QSepharose FF was applied to a Sephadex G25 (Pharmacia, LKB Biotechnology) column $(3 \times 100 \mathrm{~cm})$ and eluted at room temperature with $0.1 \mathrm{M}$ acetic acid at a flow rate of $7 \mathrm{ml} / \mathrm{min}$. Fractions of $10 \mathrm{ml}$ were collected, absorbance was measured at $280 \mathrm{~nm}$ and glucagon was determined by HPLC. The glucagon-rich fractions were pooled and lyophilized.

\section{Ion-exchange chromatography on S-Sepharose FF}

One hundred $\mathrm{mg}$ of the glucagon fraction obtained in the previous step was applied to an S-Sepharose FF (Pharmacia, LKB Biotechnology) column $(1.6 \times 10 \mathrm{~cm})$. The sample $(4 \mathrm{ml})$ containing $100 \mathrm{mg}$ of glucagon was applied to the column and eluted with $50 \mathrm{mM}$ sodium citrate buffer, $7 \mathrm{M}$ urea, $\mathrm{pH} 4.0$, at a flow rate of $2.5 \mathrm{ml} / \mathrm{min}$. Fractions of $3 \mathrm{ml}$ were collected, absorbance was measured at $280 \mathrm{~nm}$ and glucagon was determined by HPLC analysis.

\section{Pilot scale test}

The same procedure was developed at the pilot scale using the following chromatographic conditions: 1) the isoelectric precipitate dissolved in 1 liter was applied to a 37 x 45-cm Q-Sepharose FF column and eluted at a flow rate of $750 \mathrm{ml} / \mathrm{min}$; 2) 5.25 $\mathrm{ml}$ of the glucagon fraction from Q-Sepharose FF was applied to a $25 \times 120-\mathrm{cm}$ Sephadex G-25 column and eluted at a flow rate of 450 $\mathrm{ml} / \mathrm{min}$; 3) $100 \mathrm{ml}$ of the glucagon fraction from the previous step was applied to a $4.5 \mathrm{x}$ 25-cm S-Sepharose FF column and eluted at a flow rate of $10 \mathrm{ml} / \mathrm{min}$.

\section{Bioassay}

The hyperglycemic glucagon activity was tested after subcutaneous injection of the samples into rats, according to Staub et al. (8). Blood glucose concentration was determined by the method of Barhan and Trinder (16).

\section{Results}

The starting material selected for glucagon purification was the mother liquor from the alkaline insulin crystallization obtained in the industrial production of bovine insulin. This material is the major source of pancreatic glucagon (11). 
Figure 1 - Ion-exchange chromatography of glucagon on QSepharose FF. The isoelectric precipitate $(400 \mathrm{mg} / \mathrm{ml}$ eluent) was applied to a $2.0 \times 26-\mathrm{cm}$ column and eluted at room temperature with $50 \mathrm{mM}$ Tris$\mathrm{HCl}, 7 \mathrm{M}$ urea, $\mathrm{pH}$ 9.0, at a flow rate of $5.0 \mathrm{ml} / \mathrm{min}$. Fractions of $5.0 \mathrm{ml}$ were collected and the amount of glucagon was determined by RIA. The arrow indicates the fraction where the buffer $\mathrm{NaCl}$ concentration was increased to $1.0 \mathrm{M} \mathrm{NaCl}$. Absorbance at $280 \mathrm{~nm}$ (solid line), mg glucagon (dashed line).

Figure 3 - Ion-exchange chromatography of glucagon on SSepharose FF. The sample, $100 \mathrm{mg}$ of fraction B (Fr B) from Sephadex G-25 (Figure 2), was applied to a $1.6 \times 10$ $\mathrm{cm}$ column and eluted at room temperature with $50 \mathrm{mM}$ sodium citrate, $7 \mathrm{M}$ urea, $\mathrm{pH} 4.0$, at a flow rate of $2.5 \mathrm{ml} / \mathrm{min}$. Fractions of $3.0 \mathrm{ml}$ were collected and the amount of glucagon was determined by HPLC. The arrows indicate the fractions where the buffer $\mathrm{NaCl}$ concentration was increased by the addition of $\mathrm{NaCl}$. Absorbance at $280 \mathrm{~nm}$ (solid line), mg glucagon (dashed line).
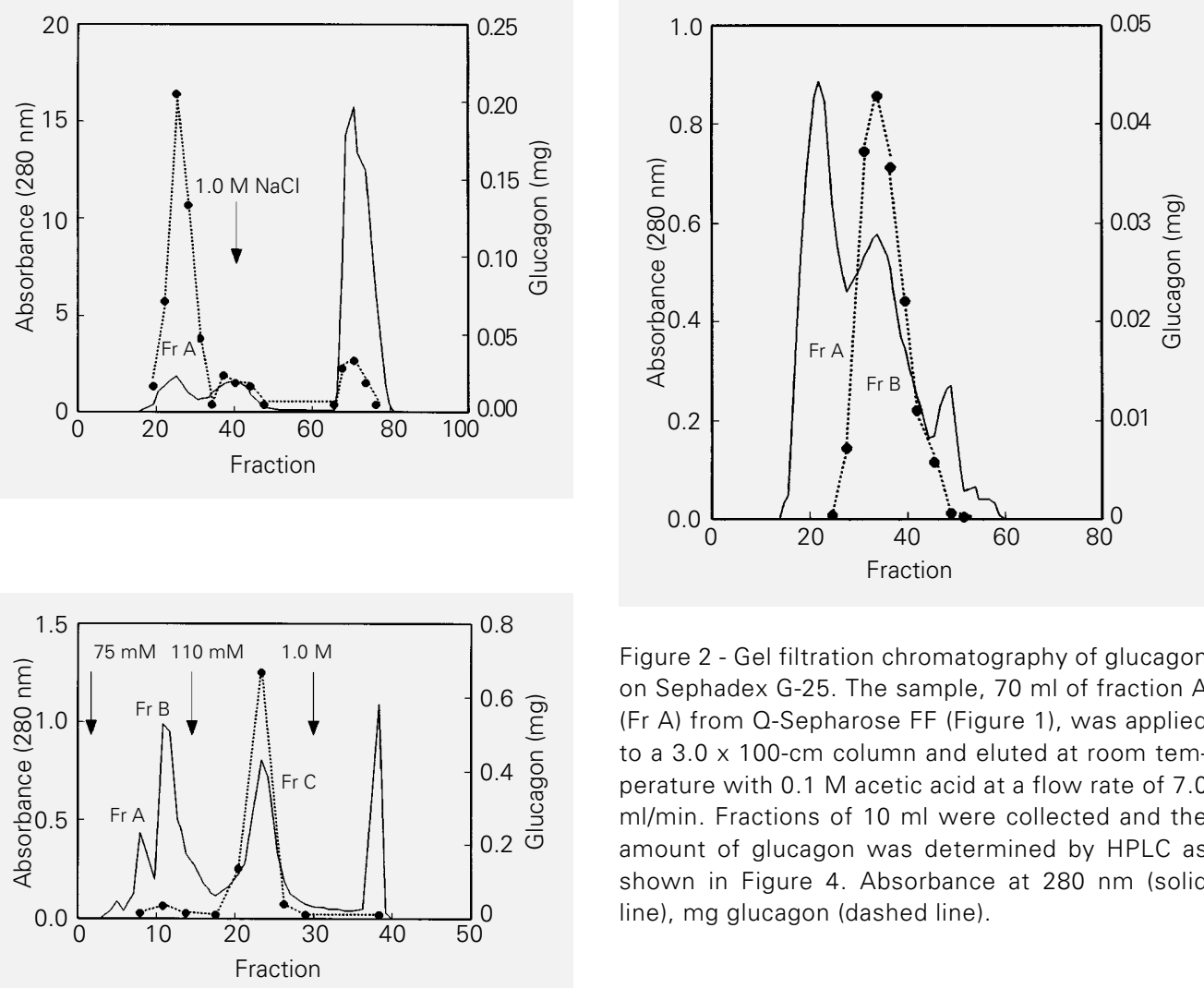

Figure 2 - Gel filtration chromatography of glucagon on Sephadex G-25. The sample, $70 \mathrm{ml}$ of fraction $A$ (Fr A) from Q-Sepharose FF (Figure 1), was applied to a $3.0 \times 100-\mathrm{cm}$ column and eluted at room temperature with $0.1 \mathrm{M}$ acetic acid at a flow rate of 7.0 $\mathrm{ml} / \mathrm{min}$. Fractions of $10 \mathrm{ml}$ were collected and the amount of glucagon was determined by HPLC as shown in Figure 4. Absorbance at $280 \mathrm{~nm}$ (solid line), mg glucagon (dashed line).

The first step of the purification process was salting-out of proteases usually present in pancreatic extracts with ammonium sulfate. Glucagon was concentrated by adjusting the $\mathrm{pH}$ to its isoelectric point, resulting in a precipitate with $1.04 \%(\mathrm{w} / \mathrm{w})$ glucagon when analyzed by RIA. The isoelectric precipitate was dissolved and applied to a QSepharose FF column (Figure 1). Glucagon was eluted mainly in the first peak, as can be seen from the radioimmunoassay data. Glucagon recovery in this step was 80 to $88 \%$ with a purification factor of 8.2 to 8.9. The glucagon fraction from Q-Sepharose FF was desalted on a Sephadex G-25 column (Figure 2). Higher molecular weight proteins were also removed, resulting in a purification factor of 3.5 to 4.0 . The recovery in this step was $74-82 \%$. The fractions containing glucagon, as indicated by HPLC, were pooled and further purified by ion-exchange chromatography on S-Sepharose FF (Figure 3).
The recovery was 76-79\% and a purification factor of 2.3 to 2.5 was obtained. The fractions containing glucagon, as indicated by HPLC, were pooled, dialyzed and lyophilized. Figure 4 shows the standard and purified glucagon HPLC analysis after the final purification step.

This procedure was utilized at the pilot scale and the results obtained in the different steps are shown in Table 1. The total recovery was $50.2 \%$ and a purification factor of 80.8 was obtained.

To measure the hyperglycemic action, purified and standard (commercial Lilly) glucagon were injected into rats. The results in Figure 5 show that glucagon obtained by the present process induced hyperglycemia at levels similar to those of standard glucagon.

\section{Discussion}

Glucagon can be produced synthetically 
$(17,18)$ but since the primary structures of porcine, bovine and human glucagon are identical, synthetic glucagon has no advantage over glucagon of bovine or porcine origin. Since the need for glucagon has not exceeded the amount that can be produced as a by-product of insulin, glucagon for clinical use will probably continue to be produced from pancreas.

The process described here for glucagon purification provides a recovery of $50 \%$ which is the same or higher when compared with other processes such as those used by Maskalick and Anderson (19), Jackson (20) and Stilz and Jackson (21), with recoveries of $44.6,33.2$ and $43.5 \%$, respectively. Among these investigators, only Jackson (20) isolated glucagon from insulin crystal mother liquors.

In addition to obtaining glucagon as a byproduct of industrial insulin production, the process presented here has an additional advantage of using chromatographic steps, mainly ion-exchange chromatography, which can be easily scaled up as documented in Table 1.

The $84 \%$ pure glucagon (HPLC analysis), which has also been characterized by amino acid analysis and protein sequencing (both of them performed at the Laboratório de Bioquímica e Química de Proteínas, Universidade de Brasília), has the necessary quality for use in pharmaceutical formulations. Furthermore, the HPLC procedure can be used to prepare at least 90\% (HPLC analysis) pure glucagon on an industrial scale (22). Finally, biological assay of glucagon obtained by this process showed its capacity to induce hyperglycemia at levels similar to those obtained with a standard glucagon preparation.
Table 1 - Pilot scale chromatographic productional glucagon.

* Determined by the method of Lowry et al. (14). \% Glucagon was determined by RIA (a) or HPLC (b). The total yield was $50 \%$.

\begin{tabular}{lcccc}
\hline Purification step & Protein* $^{*}(\mathrm{~g})$ & Glucagon (g) & Purification (x) & Yield (\%) \\
\hline Isoelectric precipitation & 225.0 & 2.34 (a) & - & - \\
Q-Sepharose FF & 22.50 & 2.05 (a) & 8.78 & 87.6 \\
Sephadex G-25 & 4.33 & 1.54 (b) & 3.90 & 75.1 \\
S-Sepharose FF & 1.397 & $1.174(\mathrm{~b})$ & 2.36 & 76.2
\end{tabular}

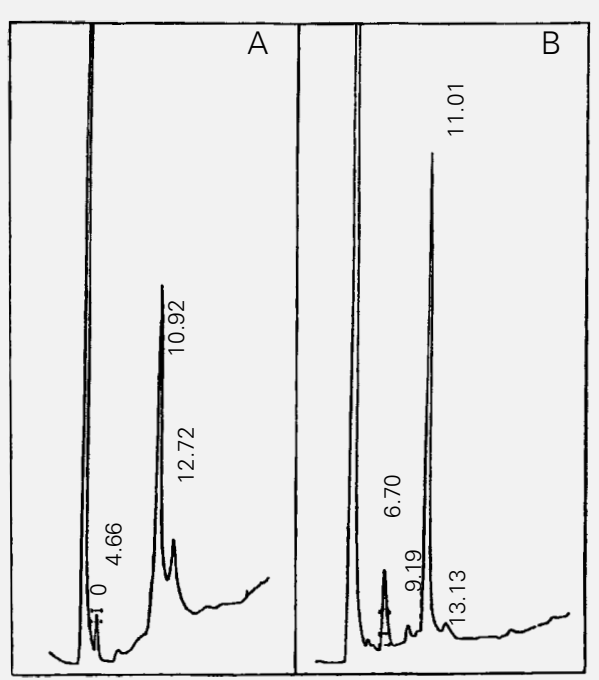

Figure 4 - Analytical characterization of glucagon by HPLC. A, Purified glucagon ( $\mathrm{Fr} C$ from $\mathrm{S}$ Sepharose FF). B, Standard glucagon. Purified and standard glucagon have the same retention time $(10.97 \pm 0.08)$ and approximately the same purity $(84.05$ and $85.2 \%$ for purified and standard glucagon, respectively). Experimental conditions: after sample application, a stepwise acetonitrile gradient consisting of $50,60,62,70$ and $80 \%$ buffer "B" (5 min per step) was used (buffer " $A$ ", 50 $\mathrm{mM}$ sodium phosphate, $10 \mathrm{mM}$ perchloric acid, $\mathrm{pH} 2.5$, and buffer "B", 50\% acetonitrile in buffer "A") in an Aquapore RP $300 \mathrm{col}-$ umn $(4.6 \times 250 \mathrm{~mm})$ at room temperature and at a flow rate of 1 $\mathrm{ml} / \mathrm{min}$. The elution was monitored by absorbance at $214 \mathrm{~nm}$.

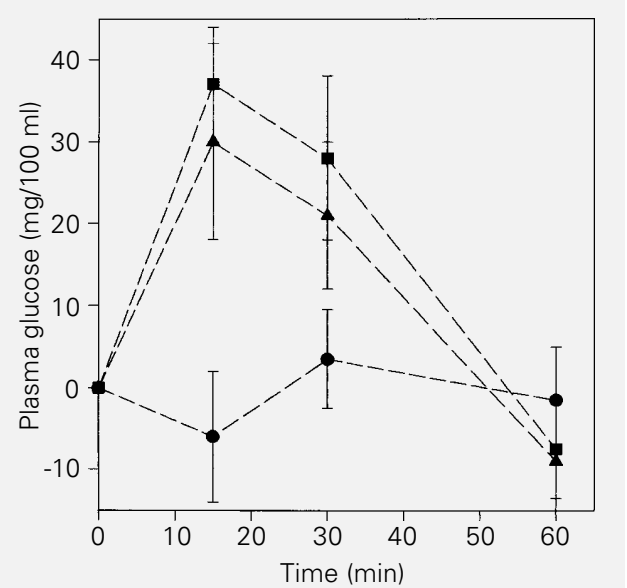

Figure 5 - Hyperglycemic action of glucagon on mice. Circles, Control (without glucagon); triangles, purified glucagon ( $\mathrm{Fr} \mathrm{C}$ from $\mathrm{S}$ Sepharose FF); squares, standard glucagon. The mice (fasted females weighing 18 to $25 \mathrm{~g}$ ) were divided into three groups (8 mice per group), which received by subcutaneous injection $2.5 \mu \mathrm{g}$ of purified glucagon ( $\mathrm{Fr} \mathrm{C}$ from SSepharose), standard glucagon or saline solution. Forty- $\mu$ l blood samples were taken and centrifuged and plasma glucose was determined by the method of Barhan and Trinder (16). Each point represents the means of six determinations. 


\section{References}

1. Bromer WW, Boucher ME \& Koffenberger JE (1971). Amino acid sequence of bovine glucagon. Journal of Biological Chemistry, 246: 2822-2827.

2. Thomsen J, Kristiansen K, Brunfeldt K \& Sudky $F$ (1971). The amino acid sequence of human glucagon. FEBS Letters, 21: 315-319.

3. Bromer WW, Sinn LG, Staub A \& Behrens OK (1956). The amino acid sequence of glucagon. Journal of the American Chemical Society, 78: 3858-3859.

4. Sherwin RJ (1976). Hyperglucagonemia and blood glucose regulations in normal obese and diabetic subjects. New England Journal of Medicine, 294: 455-461.

5. Sherwin RJ \& Felig P (1977). Glucagon physiology in health and disease. International Review of Physiology, 16: 151-171.

6. Farah A \& Tüttle R (1960). Studies on the pharmacology of glucagon. Journal of Pharmacology and Experimental Therapeutics, 129: 49-55.

7. Chernish SM \& Miller RE (1975). Glucagon as a diagnostic aid in gastrointestinal radiology. US Patent 3862321 (Cl-4244:AGIK).

8. Staub A, Sinn L \& Behrens OK (1953). Purification and crystallization of hyperglycemic glycogenolytic factor (HGF). Science, 117: 628-629.
9. Pollock HJ \& Kimmel JR (1975). Chicken glucagon: isolation and amino acid sequence studies. Journal of Biological Chemistry, 250: 9377-9380.

10. Cole RD (1960). lon exchange chromatography of glucagon in urea- containing buffers. Journal of Biological Chemistry, 235: 2300-2301.

11. Sundby F \& Markussen J (1971). Isolation, crystallization and amino acid composition of rat glucagon. Hormone and Metabolic Research, 3: 184-187.

12. Christofides ND (1982). Pancreatic glucagon. In: Bloom SR \& Long RG (Editors), Radioimmunoassay of Gut Regulatory Peptides. Praeger Publishers, London, 7479.

13. Bryant MG (1982). Radioactive labeling. In: Bloom SR \& Long RG (Editors), Radioimmunoassay of Gut Regulatory Peptides. Praeger Publishers, London, 21-27.

14. Lowry $\mathrm{OH}$, Rosebrough NJ, Farr AL \& Randall RJ (1951). Protein measurement with the Folin phenol reagent. Journal of Biological Chemistry, 193: 265-275.

15. Kunitz M (1950). Crystalline enzymes. Journal of General Physiology, 33: 349353.
16. Barhan D \& Trinder P (1972). Improved color reagent for the determination of blood glucose by oxidase system. Analyst, 97: 142-145.

17. Wünsch E (1967). Die Totalsynthese des Pankreas-Hormones Glucagon. Zeitschrift für Naturforschung, 22b: 1269-1276.

18. Lundt BF, Groenvald FC, Johansen NL \& Markussen J (1979). Synthesis of glucagon. Research Disclosure, 181: 246-247.

19. Maskalick DG \& Anderson MT (1986). Process for recovering glucagon from pancreas glands. US Patent 4.617.376 (Int. Cl. CO7K 7/34).

20. Jackson RL (1975). Process for recovering glucagon. US Patent 3.875.138 (Int. Cl. C07C.103/52)

21. Stilz JG \& Jackson RL (1977). Process for purifying glucagon. UK Patent 1.576.344 (Int. Cl. C07 67/00).

22. Oliveira S \& Vilela L (1994). Large scale reversed phase-high performance liquid chromatography purification of insulin. The Seventh International Conference of Biological Products. The Engineering Foundation and The American Chemical Society, San Diego, CA, USA. 